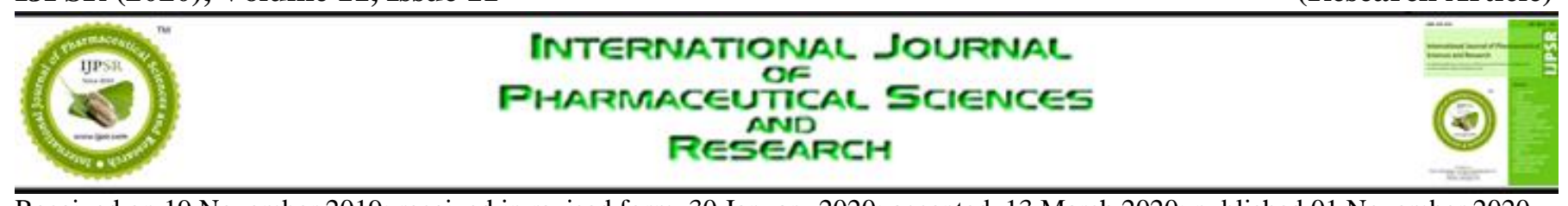

Received on 19 November 2019; received in revised form, 30 January 2020; accepted, 13 March 2020; published 01 November 2020

\title{
VALIDATED STABILITY INDICATING HPLC METHOD FOR ESTIMATION OF CAPECITABINE
}

K. V. Lalitha ${ }^{*}{ }^{1}$, J. Raveendra Reddy ${ }^{1}$ and N. Devanna ${ }^{2}$

Division of Pharmaceutical Analysis and Quality Assurance ${ }^{1}$, Raghavendra Institute of Pharmaceutical Education and Research (RIPER) - Autonomous Ananthapuramu - 515172, Andhra Pradesh, India. Jawaharlal Nehru Technological University - OTPRI ${ }^{2}$, Ananthapuramu - 515002, Andhra Pradesh, India.

Keywords:

Capecitabine, HPLC,

Degradation, Stability studies

Correspondence to Author:

K. V. Lalitha

Assistant Professor,

Division of Pharmaceutical Analysis and Quality Assurance, Raghavendra Institute of Pharmaceutical Education and Research (RIPER) - Autonomous Ananthapuramu - 515172, Andhra Pradesh, India.

E-mail: lalithapadmavathi.lalitha@gmail.com

\begin{abstract}
A new stability-indicating high-performance liquid chromatographic method of analysis of capecitabine in pharmaceutical dosage form was developed and validated. The solvent system consisted of methanol: water $(60: 40 \% \mathrm{v} / \mathrm{v})$. The retention time of capecitabine was $7.927 \mathrm{~min}$ at a flow rate of $1 \mathrm{ml} / \mathrm{min}$ on C-18 (Quails BDS, $250 \times 4.6 \mathrm{~mm}, 5 \mu)$. Capecitabine was detected at $240 \mathrm{~nm}$. The linear regression analysis data for the linearity plot showed good linear relationship with the correlation coefficient value, $\mathrm{R}^{2}=0.9991$ in the concentration range $4-50 \mu \mathrm{g} / \mathrm{ml}$. The method was validated according to the ICH guidelines. The accuracy of the method was validated by recovery studies and was found to be significant and under specification limits, with Recovery 98.12-101.61\%. The assay of capecitabine was determined in tablet dosage form. The method was also found to be robust. The drug was subjected to stress conditions of acidic, basic, oxidation, photolytic and thermal degradation, and considerable degradation was found in all stress conditions. The method has proven specificity for the stability-indicating method.
\end{abstract}

INTRODUCTION: Capecitabine is an antineoplastic carbamate of fluoropyrimidine, and it is used in the category of anti-metabolites medicinal drugs. Capecitabine is a chemotherapy agent orally used to treat metastatic and colorectal cancers. Capecitabine is a 5'-deoxy-5-fluorouridine (5'-DFUR) drug which inhibits the synthesis of DNA and slowns the growth of tumor-tissue in cells.

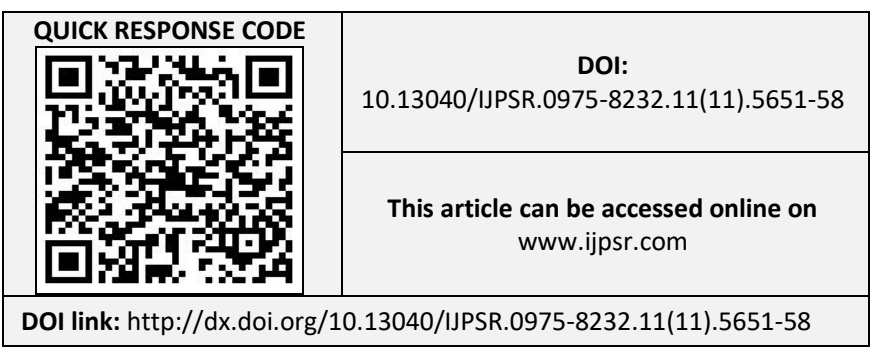

This induces the pharmacodynamic response by representing a natural nutrient in cells necessary for the growth of cancer cells. Capecitabine is taken up by the cancer cells and then impairs their growth ${ }^{1-}$ 4. The literature review indicates that few experimental approaches have been used to measure capecitabine by HPLC ${ }^{5-8}$. Table 1 shows the list of formulations of capecitabine available in market.

\section{Drug Profile of Capecitabine: ${ }^{9}$}

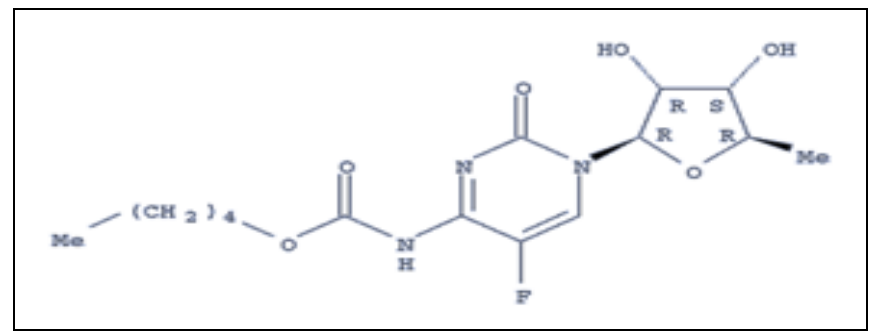




\section{DRUG PROFILE OF CAPECITABINE}

\begin{tabular}{|c|c|c|}
\hline Molecular formula & : & $\mathrm{C}_{15} \mathrm{H}_{22} \mathrm{FN}_{3} \mathrm{O}_{6}$ \\
\hline Structure & : & Capecitabine \\
\hline Chemical name & : & $\begin{array}{l}\text { Pentyl N-\{1-[(2R, 3R, } 4 \mathrm{~S} \text {, } \\
5 \mathrm{R})-3,4 \text {-dihydroxy-5- } \\
\text { methyloxolan-2-yl]-5- } \\
\text { fluoro-2- oxo-1, 2- } \\
\text { dihydropyrimidin-4- } \\
\text { yl \}carbamate }\end{array}$ \\
\hline Molecular weight & : & $359.3501 \mathrm{~g} / \mathrm{mol}$ \\
\hline Description & : & $\begin{array}{l}\text { White to off-white } \\
\text { crystalline powder }\end{array}$ \\
\hline Solubility & : & $\begin{array}{l}\text { Soluble in water and } \\
\text { slightly soluble in methanol }\end{array}$ \\
\hline Melting Range & : & $110-121^{\circ} \mathrm{C}$ \\
\hline pka & : & 12.59 \\
\hline Category & : & $\begin{array}{l}\text { Anti-neoplastic agent, Anti- } \\
\text { metabolites and prodrugs }\end{array}$ \\
\hline \multicolumn{3}{|l|}{ Pharmacokinetic Data } \\
\hline Bioavailability & : & Extensive \\
\hline Protein binding albumin) & : & less than $60 \%$ (mainly \\
\hline Metabolism & : & $\begin{array}{l}\text { Hepatic, to } 5^{\prime} \text { - DFCR, } 5^{\prime} \text { - } \\
\text { DFUR (inactive); neoplastic } \\
\text { tissue, } 5^{\prime} \text {-DFUR to active } \\
\text { fluorouracil }\end{array}$ \\
\hline Half-life & : & $45-60 \mathrm{~min}$ \\
\hline Excretion & : & $\begin{array}{l}\text { Predominantly excreted in } \\
\text { urine }\end{array}$ \\
\hline Dosage form & : & Tablet \\
\hline Dose & : & $150 \mathrm{mg}, 500 \mathrm{mg}$ \\
\hline Wavelength $\left(\lambda_{\max }\right)$ & : & $239 \mathrm{~nm}$ \\
\hline Official Monograph & : & USP \\
\hline
\end{tabular}

TABLE 1: LIST OF FORMULATIONS OF CAPECITABINE AVAILABLE IN MARKET

\begin{tabular}{ccccc}
\hline $\begin{array}{c}\text { S. } \\
\text { no. }\end{array}$ & $\begin{array}{c}\text { Brand } \\
\text { name }\end{array}$ & Dose & $\begin{array}{c}\text { Dosage } \\
\text { form }\end{array}$ & Manufacturer \\
\hline 1 & XELODA & $150 \mathrm{mg} / 500 \mathrm{mg}$ & Tablet & Roche \\
2 & XABINE & $500 \mathrm{mg}$ & Tablet & Ranbaxy \\
3 & ZOCTAB & $500 \mathrm{mg}$ & Tablet & Dabur \\
4 & CAPEGARD & $500 \mathrm{mg}$ & Tablet & Cipla \\
5 & CAPIIBINE & $150 \mathrm{mg} / 500 \mathrm{mg}$ & Tablet & $\begin{array}{c}\text { Dr . Reddy's } \\
6\end{array}$ \\
CACIT & $500 \mathrm{mg}$ & Tablet & Biochem \\
7 & CAPEBIN & $500 \mathrm{mg}$ & Tablet & Oncare \\
\hline
\end{tabular}

\section{EXPERIMENTAL:}

Chemicals and Reagents: HPLC grade methanol and water were purchased from Merck Company, Mumbai, India.

\section{Method Development:}

Preparation of Standard Drug Solutions: Stock solution of Capecitabine was prepared by dissolving $10 \mathrm{mg}$ of Capecitabine in separate 10 $\mathrm{mL}$ of the volumetric flask with a small quantity of water. The mixture was sonicated for about $10 \mathrm{~min}$ and then made up to volume with water. From the stock solution, $100 \mu \mathrm{g} / \mathrm{mL}$ of capecitabine was prepared.
Chromatographic Conditions: The mobile phase consisted of methanol, and water was filtered before use by means of a $0.45 \mu$ membrane in a ratio of 60 to 40 composition of the mobile phase. The mobile phase was supplied with a flow rate of 1.0 $\mathrm{ml} / \mathrm{min}$ from the solvent reservoir into the tank, and the injection volume was $20 \mu \mathrm{l}$. The temperature of the column was kept at $23 \pm 10{ }^{\circ} \mathrm{C}$. At $239 \mathrm{~nm}$, eluent controls were performed. The optimized conditions were shown in Table 2.

Calibration of Standards: The standard calibration line was constructed for capecitabine. In order to achieve a concentration of $4-50 \mu \mathrm{g} / \mathrm{ml}$ of different capecitabine volumes of the stock, solutions have been correctly transferred to $10 \mathrm{ml}$ volumetric cylindrical flasks. The reference line was achieved by diagraming the peak area of product concentration.

Method Validation: The method was validated according to the ICH guidelines. The following validations characteristics were addressed: specificity and selectivity, linearity, assay, accuracy, precision, limits of detection and quantitation, robustness, ruggedness ${ }^{10-12}$.

Specificity and Selectivity: Due to the presence of other excipients, the specificity of the method was assessed for interference. The figure shows that the medicinal product was clearly separated. This study therefore selects the HPLC method presented.

Linearity: The linearity of calibration curves in a pure solution (peak area $v s$.) was tested over the 4$50 \mu \mathrm{g} / \mathrm{ml}$ range. The regression lines for standard drug concentrations using an analysis of regression were lined with the calibration curves and $\mathrm{y}=$ $53752 x+48825, r^{2}=0.991$ for capecitabine. Total eluting time was less than $10 \mathrm{~min}$. The mean \pm standard difference (SD) was determined for the pitch, intercept, and correlation coefficient of the standard curves $(\mathrm{N}=3)$. Table 3-4 and Fig. 1 presented the data.

Precision: Six duplicate measurements of 20 $\mu \mathrm{g} / \mathrm{mL}$ capecitabine concentration were tested for process accuracy; the results shown in Table 23. In order to determine process precision, intraday and inter-day measurements (days 3) of the drug were performed, using $8 \mu \mathrm{g} / \mathrm{mL}, 20 \mu \mathrm{g} / \mathrm{mL}, 40 \mathrm{~mL}$, intraday, and inter-day samples were calibrated with a 
standard curve simultaneously prepared during the day of testing by calibrating percent RSD for replicate samples $(n=3)$. Table $\mathbf{7 - 8}$ revealed the intra-and inter-day accuracy tests.

Assay: The analysis was carried out by weighing 10 comprises a finely powdered tablet powder equivalent to the $10 \mathrm{mg}$ of API and was precisely weighed. This was obtained with $10 \mathrm{ml}$ flask water and added water to label the solution with filtering paper from Whatman $1(1000 \mathrm{mcg} / \mathrm{ml})$. The volume was added with the moving phase $(100 \mathrm{mcg} / \mathrm{ml})$, and $1 \mathrm{ml}$ was transferred into a $10 \mathrm{ml}$ volumetric flask, then moved to the $10 \mathrm{ml}$ volumetric flask, and the volume upgraded to the mark with a moving phase $(10 \mathrm{mcg} / \mathrm{ml})$. The solution was sonicated for $15 \mathrm{~min}$, and the total area was measured under above chromatographic conditions.

The analysis process was done triple, and sample weight was determined for the test. Table 5 measured and displayed the percentage of products present in type, medium, and standard deviation.

Accuracy: Recovery tests have determined the reliability of the system. The drug's reference levels have been applied to the term at the rate of $50 \%$, $100 \%$, 150\%. Recovery experiments have been conducted three times, and Table 6 and Fig. 2 have measured the percent recovery and relative standard deviation from the capecitabine recovery.

Limits of Detection and Quantitation: Samples containing very low analyte levels are carried out in compliance with the ICH Guidelines for the LOD and LOQ (Limit of Quantitation) detection for the procedure. Using the mathematical formulation process, LOD has been represented by setting the minimum level to reliably detect the analyte. LOQs in the criteria that can be calculated reproducibly with reasonable precision is known as the lowest concentration of analytes. Table $\mathbf{1 0}$ showed the LOD and LOQ values for Capecitabine.

Robustness: The method's robustness was assessed through examination of system suitability requirements and measurement of system suitability parameters by varying HPLC pump flow rates $( \pm 0.2 \%)$ and organic solvents $( \pm 2 \%)$ and mobile phase 60 . No changes in the R.S.D. peak area, USP tailing factor and conceptual tiles caused any significant changes. While retention periods were much longer and statistical improvements were still possible. Table 9 revealed the results.

System Suitability: Tests are characterized as the methods that can produce an appropriate precision and accuracy. Following the development and validation of the process, the device suitability was performed. This was done by measuring parameters such as plate $(\mathrm{N})$, resolution $(\mathrm{R})$, tailor, capacity factor, HETP, sample maximum symmetry, and displayed in Table 11-12.

\section{Stress Degradation Studies of Capecitabine:}

Acid Degradation Studies: Acid decomposition studies were carried out in $0.1 \mathrm{~N} \mathrm{HCl}$ at room temperature for a period of 3 days. $10 \mathrm{mg}$ of the standard capecitabine was weighed and transferred to separate $10 \mathrm{ml}$ standard volumetric flasks. The drug was dissolved by adding water to get the final conc. of $1000 \mu \mathrm{g} / \mathrm{ml}$. From the above solutions, $1 \mathrm{ml}$ of capecitabine solution was drawn in to separate $10 \mathrm{ml}$ std flasks and made up to the volume with 9 $\mathrm{ml}$ of $0.1 \mathrm{~N} \mathrm{HCl}$ to get the conc. of $100 \mu \mathrm{g} / \mathrm{ml}$.

From this solution, $2 \mathrm{ml}$ of capecitabine was drawn at time periods of $0 \mathrm{~h}, 1 \mathrm{~h}, 2 \mathrm{~h}$, and $4 \mathrm{~h}$, then added $4 \mathrm{ml}$ of mobile phase and $\mathrm{pH}$ was adjusted to 4.0 with OPA. The volume was developed and injected with up to $10 \mathrm{ml}$ mobile phase. As a controller, Blank was used (sample solution without the medicine) to determine mobile phase interference. Table 13-14 showed the findings.

Alkaline Degradation Studies: The analysis of alkaline decomposition at room temperature was carried out in $0.1 \mathrm{NaOH}$. The Capecitabine formulation weighed $10 \mathrm{mg}$ and was moved to a generic $10 \mathrm{ml}$ volumetric container. The drugs are dissolved in water to achieve the final concentration of $1000 \mu \mathrm{g} / \mathrm{ml} 1 \mathrm{ml}$ of capecitabine from the above solutions were drawn in regular $10 \mathrm{ml}$ containers, and the conc volume was made up of $0.1 \mathrm{~N} \mathrm{NaOH} 9 \mathrm{ml} 100 \mu \mathrm{g} / \mathrm{ml} 100 \mu \mathrm{g}$. The $2 \mathrm{ml}$ Cacpecitabine solution has been drawn at $0 \mathrm{~h}, 1 \mathrm{~h}$, $2 \mathrm{~h}$, and $4 \mathrm{~h}$, and then $4 \mathrm{ml}$ of the mobile stage has been applied, and the PH with OPA has been changed to 4.0. The amount was up to $10 \mathrm{ml}$ and injected into the mobile phase. As a control, blank (sample solution without medicine) has been used, and mobile phase interference has been determined.

Table 15-16 showed the results. 
Neutral Condition: A separate $10-\mathrm{ml}$ volumetric flask was drawn from the stock solution for standard capecitabine $1 \mathrm{ml}$, which is composed of the amount of $9 \mathrm{ml}$ water for finally conc. $100 \mu \mathrm{g}$ per $\mathrm{ml} .1 \mathrm{ml}$ of capecitabine was drawn and injected from these solutions into $10 \mathrm{ml}$ volumetric flask, with a volume of $0 \mathrm{~h}, 1 \mathrm{~h}, 2 \mathrm{~h}$, and $4 \mathrm{~h}$.

Oxidative Degradation Studies: In order to achieve a final conc. of $10 \mathrm{ml}$ volumetric flask, $1 \mathrm{ml}$ each was drawn from a stock solution with standard Capecitabine 100 microns $/ \mathrm{ml}$. $2 \mathrm{ml}$ Capecitabine from these solutions were drawn in $10 \mathrm{ml}$ volumetric bottle with the following dimensions: 0 $\mathrm{h}, 1 \mathrm{~h}, 2 \mathrm{~h}$, and $4 \mathrm{~h}$ and made up to the volume with the mobile phase and injected. Stress specimens deteriorated from the highest areas in the chromatogram. The damaged substance content was determined by percentage. Table 17-18 shows the results. $0.3 \% \mathrm{H}_{2} \mathrm{O}_{2}$ oxidative stress tests have been performed at room temperature.

Thermal Degradation Studies: Thermal degradation studies for both drug solutions were conducted by exposing the sample at $60{ }^{\circ} \mathrm{C}$ for $0 \mathrm{~h}$, $1 \mathrm{~h}, 2 \mathrm{~h}$ and $4 \mathrm{~h}$ in hot air oven.

$10 \mathrm{mg}$ of capecitabine was measured into a different $10 \mathrm{ml}$ bottle; the medicine was dissolved with a few $\mathrm{ml}$ of water and then diluted with air until the mark was over. Solution of $1000 \mu \mathrm{g} / \mathrm{ml}$. 1 $\mathrm{ml}$ of capecitabine has been drawn from the above solutions into a $10 \mathrm{ml}$ volumetric flask, up to a volume of water to achieve a final conc. $100 \mu \mathrm{g}$ per liter. This solution was exposed to $60{ }^{\circ} \mathrm{C}$ and $2 \mathrm{ml}$ capecitabine was drawn to the final volume at $0 \mathrm{~h}$, $1 \mathrm{~h}, 2 \mathrm{~h}$ and $4 \mathrm{~h}$. Stress specimens suffered from the highest areas in the chromatogram, determined the percentage level of the damaged drug. Table 19-20 shows the findings. The results are shown.

Photolytic Degradation Studies: Photo stability degradation studies of capecitabine solution was carried out in a photostability chamber by exposing to UV light. Weighed $10 \mathrm{mg}$ of capecitabine into $10 \mathrm{ml}$ flasks and dissolved it with only a few $\mathrm{ml}$ liquid and diluted it with water to get eventually conc. of $1000 \mu \mathrm{g} / \mathrm{ml}$. $1 \mathrm{ml}$ of capecitabine has been drawn from the above solutions to $10 \mathrm{ml}$ volumetric bottle and composed up to the volume of water to finish conc. $100 \mu \mathrm{g} / \mathrm{ml}$.
The solutions were drawn up and pumped into the last volume at $0 \mathrm{~h}, 1 \mathrm{~h}, 2 \mathrm{~h}$ and $4 \mathrm{~h}$ in the stability chamber with $2 \mathrm{ml}$ capecitabine. Stress specimens were removed from the peak areas in the chromatogram. The deteriorated drug percentage was identified Table 21-22 show the results. The results are tabled.

\section{RESULTS:}

\section{Validation of Analytical Method for the Assay of Capecitabine:}

\begin{tabular}{|c|c|c|}
\hline S. no. & Parameter & Result \\
\hline 1 & Mobile Phase & $\mathrm{MeOH}$ : Water \\
\hline 2 & Ratio & 60: 40 \\
\hline 3 & Detector & PDA \\
\hline 4 & Detection Wavelength & $239 \mathrm{~nm}$ \\
\hline 5 & $\begin{array}{c}\text { Column } \\
\text { (Stationary Phase) }\end{array}$ & $\begin{array}{c}\mathrm{C} 18250 \times 4.5 \mathrm{~mm} \text { id } \\
5 \mu \mathrm{m}\end{array}$ \\
\hline 6 & Flow Rate & $1 \mathrm{ml} / \mathrm{min}$ \\
\hline 7 & Column Temp. & $23{ }^{\circ} \mathrm{C}$ \\
\hline 8 & Retention time & 7.927 \\
\hline 9 & Volume of injection $(\mu \mathrm{L})$ & 20 \\
\hline
\end{tabular}

Specificity: Specificity is the ability of a method to discriminate between the intended analyte(s) and other components in the sample. Specificity of the HPLC method is demonstrated by the separation of the analytes from other potential components such as impurities, degradants, or excipients. Volume of $20 \mu \mathrm{L}$ of working placebo sample solution was injected into the chromatograph and the chromatogram was recorded and presented below. No peaks were found at retention time of 7.927. As no peaks were found at retention time of 7.927, the proposed method was specific for the detection of capecitabine.

\section{Linearity and Range:}

TABLE 3: LINEARITY RANGE DATA FOR CAPECITABINE

\begin{tabular}{cccc}
$\begin{array}{c}\text { S. } \\
\text { no. }\end{array}$ & $\begin{array}{c}\text { Concentration } \\
(\boldsymbol{\mu} \mathbf{g} / \mathbf{m l})\end{array}$ & $\begin{array}{c}\text { Peak area } \\
\text { Mean } \pm \text { SD }(\mathbf{n}=\mathbf{3})\end{array}$ & \%RSD \\
\hline 1 & 4 & $612770 \pm 6824.3$ & 1.1136 \\
2 & 8 & $906752 \pm 8639.7$ & 0.9528 \\
3 & 12 & $1128061 \pm 8824.2$ & 0.7822 \\
4 & 16 & $1406413 \pm 8039.8$ & 0.5715 \\
5 & 20 & $1625569 \pm 17324.6$ & 1.0657 \\
6 & 24 & $1905515 \pm 19876.3$ & 1.0435 \\
7 & 28 & $2232432 \pm 19763.9$ & 0.8852 \\
8 & 32 & $2478652 \pm 21987.7$ & 0.8870 \\
9 & 36 & $2705543 \pm 22465.1$ & 0.8303 \\
10 & 40 & $2971512 \pm 23363.5$ & 0.7862 \\
11 & 50 & $3701589 \pm 27864.2$ & 0.7527 \\
\hline
\end{tabular}




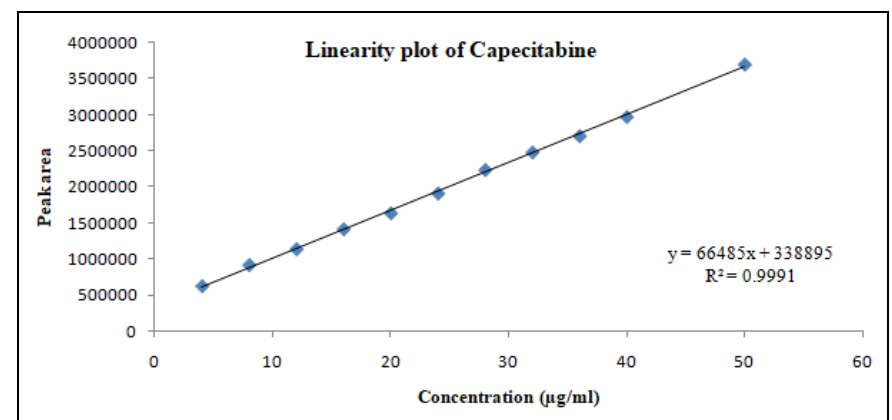

FIG. 1: LINEARITY PLOT OF CAPECITABINE
TABLE 4: LINEARITY REPORT OF CAPECITABINE

\begin{tabular}{|c|c|c|}
\hline S. no. & Parameter & Values for Capecitabine \\
\hline 1 & $\begin{array}{l}\text { Linearity } \\
\text { range }\end{array}$ & $4-50 \mu \mathrm{g} / \mathrm{ml}$ \\
\hline 2 & $\begin{array}{c}\text { Regression } \\
\text { equation }\end{array}$ & $Y=66485 x+338895$ \\
\hline 3 & $\begin{array}{l}\text { Correlation } \\
\text { coefficient }\end{array}$ & 0.9991 \\
\hline 4 & Intercept & 338895 \\
\hline 5 & Slope & 66485 \\
\hline
\end{tabular}

Assay:

TABLE 5: ASSAY OF CAPECITABINE FORMULATION

\begin{tabular}{cccccc}
\hline S. no. & Formulation & Label claimed $(\mathbf{m g} / \mathbf{t a b})$ & Amount found $(\mathbf{m g})(\mathbf{n}=\mathbf{3})$ & Assay & \%RSD \\
\hline 1 & Capiibine & $150 \mathrm{mg}$ & $152.15 \mathrm{mg}$ & $101.43 \%$ & 0.657 \\
\hline
\end{tabular}

\section{Accuracy:}

TABLE 6: RECOVERY REPORT OF CAPECITABINE

\begin{tabular}{cccccccc}
\hline $\begin{array}{c}\text { QC conc. } \\
(\boldsymbol{\mu g} / \mathbf{m l}) \\
(\mathbf{A})\end{array}$ & $\begin{array}{c}\text { Recovery } \\
\text { level }\end{array}$ & $\begin{array}{c}\text { Added } \\
\mathbf{d r u g} \\
(\boldsymbol{\mu g} / \mathbf{m l})(\mathbf{B})\end{array}$ & $\begin{array}{c}\text { Total amount of } \\
\mathbf{d r u g}(\boldsymbol{\mu g} / \mathbf{m l})(\mathbf{A}+\mathbf{B})\end{array}$ & $\begin{array}{c}\text { Peak Area Mean } \\
\mathbf{\pm} \mathbf{S D}(\mathbf{n}=\mathbf{3})\end{array}$ & $\begin{array}{c}\text { Amount } \\
\text { found } \\
(\boldsymbol{\mu g} / \mathbf{m l})\end{array}$ & $\begin{array}{c}\text { \% } \\
\text { recovery }\end{array}$ & $\%$ RSD \\
\hline & 50 & 10 & 30 & $2382957 \pm 25864$ & 30.4347 & 101.4490 & 1.0853 \\
20 & 100 & 20 & 40 & $3069341 \pm 33847$ & 40.6754 & 101.6135 & 1.1028 \\
& 150 & 30 & 50 & $3600747 \pm 50958$ & 49.0614 & 98.1229 & 1.3406 \\
\hline
\end{tabular}

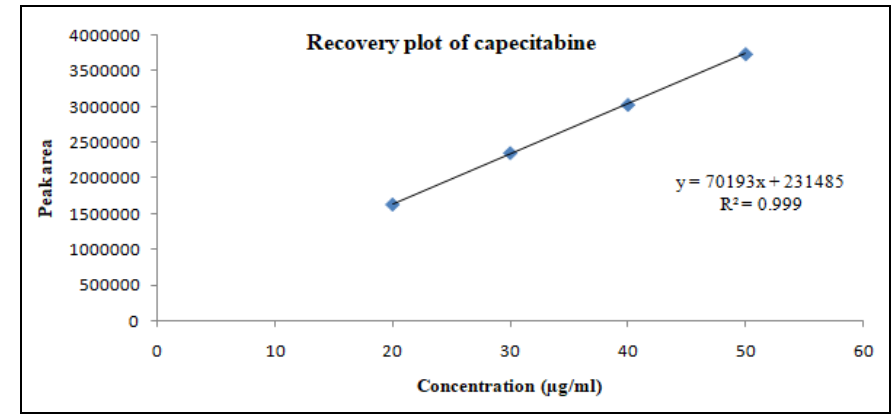

FIG. 2: RECOVERY PLOT OF CAPACETABINE

\section{Precision:}

TABLE 7: SYSTEM PRECISION DATA

\begin{tabular}{|c|c|c|c|c|c|}
\hline & Drug & Conc. $(\mu \mathrm{g} / \mathrm{ml})$ & \multicolumn{2}{|c|}{ Peak area mean \pm S.D $(n=6)$} & \% RSD \\
\hline \multicolumn{2}{|c|}{ Capecitabine } & 20 & \multicolumn{2}{|c|}{$1648537 \pm 16834.5$} & 212 \\
\hline \multicolumn{6}{|c|}{ TABLE 8: INTRA AND INTER-DAY PRECISION OF CAPECITABINE } \\
\hline S. no. & Conc. $(\mu \mathrm{g} / \mathrm{ml})$ & $\begin{array}{c}\text { Intraday }(\mathbf{n}=\mathbf{3}) \\
\text { Mean } \pm \text { SD }\end{array}$ & $\begin{array}{c}\text { Intraday } \\
\text { \% RSD }\end{array}$ & $\begin{array}{c}\text { Interday }(\mathbf{n}=\mathbf{3}) \\
\text { Mean } \pm \text { SD }\end{array}$ & $\begin{array}{c}\text { Interday } \\
\text { \% RSD }\end{array}$ \\
\hline 1 & LQC(8) & $953587.7 \pm 10208.67$ & 1.070 & $1619319 \pm 10066.45$ & 0.621 \\
\hline 2 & MQC(20) & $1864129 \pm 15363.69$ & 0.824 & $1732015 \pm 15275.25$ & 0.881 \\
\hline 3 & HQC(40) & $3742676 \pm 58890$ & 1.573 & $1552784 \pm 14422.21$ & 0.928 \\
\hline
\end{tabular}

\section{Robustness:}

TABLE 9: ROBUSTNESS STUDIES OF CAPECITABINE

\begin{tabular}{cccccc}
\hline S. no. & Parameter & Optimized parameter & Modification & Retention time & Asymmetry \\
\hline 1 & Flow rate & $1 \mathrm{ml}$ & 0.8 & 10.320 & 1.20 \\
& & & 1.2 & 6.853 & 1.15 \\
2 & \multirow{2}{*}{ Mobile phase composition } & \multirow{2}{*}{$20: 40$} & $58: 42$ & 9.167 & 0.95 \\
& & & $62: 38$ & 7.213 & 1.19 \\
3 & \multirow{2}{*}{ Wave length } & & $237 \mathrm{~nm}$ & 7.967 & 1.16 \\
& & & $241 \mathrm{~nm}$ & 7.967 & 1.16 \\
\hline
\end{tabular}


Limit of Detection (LOD) and Limit of Quantification (LOQ)

TABLE 10: LOD AND LOQ REPORT OF DRUGS

\begin{tabular}{cccc}
\hline S. no. & Drug & LOD & LOQ \\
\hline 1 & $\begin{array}{c}\text { Capecitabine } \\
(20 \mu \mathrm{g} / \mathrm{ml})\end{array}$ & $1.477 \mu / \mathrm{ml}$ & $4.470 \mu / \mathrm{ml}$ \\
\hline
\end{tabular}

\section{System Suitability:}

TABLE 11: SYSTEM SUITABILITY DATA OF CAPECITABINE

\begin{tabular}{ccccc}
\hline Drug & $\begin{array}{c}\text { Conc. } \\
(\boldsymbol{\mu g} / \mathbf{m l})\end{array}$ & $\begin{array}{c}\text { Retenti- } \\
\text { on time }\end{array}$ & $\begin{array}{c}\text { Peak area } \\
(\mathbf{n}=3) \\
\text { Mean } \pm \text { SD }\end{array}$ & $\begin{array}{c}\text { Theoretical } \\
\text { plates }\end{array}$ \\
\hline Capecitabine & 20 & 7.927 & $3075298 \pm$ \\
& & & 16800.89 & 6814 \\
\hline
\end{tabular}

TABLE 12: SYSTEM SUITABILITY PARAMETERS FOR CAPECITABINE

\begin{tabular}{cccc}
\hline $\begin{array}{c}\text { S. } \\
\text { no. }\end{array}$ & Parameter & $\begin{array}{c}\text { Values } \\
\text { obtained }\end{array}$ & $\begin{array}{c}\text { Acceptance } \\
\text { criteria }\end{array}$ \\
\hline 1 & Retention time & 7.927 & --- \\
2 & Theoretical plates & 6814 & $>2000$ \\
3 & Peak area & 3085506 & -- \\
4 & Peak Asymmetry & 1.04 & $\leq 2$ \\
5 & \% RSD & 0.54 & $\leq 2$ \\
\hline
\end{tabular}

Stress Degradation Studies for Capecitabine: Degradation Behavior of Capecitabine:

Degradation in Acid:

TABLE 13: ACIDIC DEGRADATION OF CAPECITABINE AT ROOM TEMPERATURE

\begin{tabular}{cccc}
$\begin{array}{c}\text { S. } \\
\text { no. }\end{array}$ & Time (h) & $\begin{array}{c}\text { Peak area(n=3) } \\
\text { Mean } \pm \text { SD }\end{array}$ & $\begin{array}{c}\text { \% } \\
\text { Degradation }\end{array}$ \\
\hline 1 & 0 & 1808995 & --- \\
& & \pm 5247.992 & \\
2 & 2 & 1579488 & 12.50 \\
& & \pm 12222.44 & \\
3 & 4 & 1234106 & 31.52 \\
& & \pm 10987.96 & \\
\hline
\end{tabular}

TABLE 14: DEGRADANTS FORMED DURING ACIDIC DEGRADATION AT ROOM TEMPERATURE

\begin{tabular}{cccc}
\hline $\begin{array}{c}\text { S. } \\
\text { no. }\end{array}$ & Degradants & $\begin{array}{c}\text { Retention } \\
\text { time }\end{array}$ & $\begin{array}{c}\text { Peak area }(\mathbf{n}=\mathbf{3}) \\
\text { Mean } \pm \text { SD }\end{array}$ \\
\hline 1 & $\mathrm{D}_{1}$ & 2.90 & $70137.67 \pm 247.0432$ \\
2 & $\mathrm{D}_{2}$ & 3.14 & $36151.33 \pm 146.5515$ \\
3 & $\mathrm{D}_{3}$ & 3.61 & $13732.02 \pm 116.1551$ \\
4 & $\mathrm{D}_{4}$ & 5.22 & $18680.67 \pm 111.0195$ \\
\hline
\end{tabular}

Discussion: The drug showed liability to acid hydrolysis at room temperature. It decomposed to the extent of $12.50 \%$ degradation in $0.1 \mathrm{~N} \mathrm{HCl}$ in 2 $\mathrm{h}$. The degradation increased to $31.52 \%$ in $4 \mathrm{~h}$.
Degradation in Base:

TABLE 15: ALKALI DEGRADATION OF CAPECITABINE AT ROOM TEMPERATURE

\begin{tabular}{cccc}
\hline S. no. & $\begin{array}{c}\text { Time } \\
\text { (h) }\end{array}$ & $\begin{array}{c}\text { Peak area(n=3) } \\
\text { Mean } \pm \text { SD }\end{array}$ & $\begin{array}{c}\text { \% } \\
\text { Degradation }\end{array}$ \\
\hline 1 & 0 & $2098438 \pm 11516.52$ & --- \\
2 & 2 & $1717719 \pm 10958.53$ & 18.05 \\
3 & 4 & $1406143 \pm 9729.189$ & 32.92 \\
\hline
\end{tabular}

TABLE 16: DEGRADANTS FORMED DURING ALKALI DEGRADATION AT ROOM TEMPERATURE

\begin{tabular}{cccc}
\hline $\begin{array}{c}\text { S. } \\
\text { no. }\end{array}$ & Degradants & $\begin{array}{c}\text { Retention } \\
\text { time }\end{array}$ & $\begin{array}{c}\text { Peak area } \\
\text { Mean } \pm \text { SD }\end{array}$ \\
\hline 1 & $\mathrm{D}_{1}$ & 2.507 & $6674.02 \pm 77.8267$ \\
2 & $\mathrm{D}_{2}$ & 4.787 & $9894.33 \pm 42.8291$ \\
3 & $\mathrm{D}_{3}$ & 6.487 & $6512.06 \pm 25.5342$ \\
\hline
\end{tabular}

Discussion: The drug showed liability to alkali hydrolysis at room temperature. It decomposed to the extent of $18.05 \%$ degradation in $0.1 \mathrm{~N} \mathrm{NaOH}$ in $2 \mathrm{~h}$. The degradation increased to $32.92 \%$ in $4 \mathrm{~h}$.

Oxidative Stress Study:

TABLE 17: OXIDATIVE DEGRADATION OF CAPECITABINE AT ROOM TEMPERATURE

\begin{tabular}{cccc}
\hline $\begin{array}{c}\text { S. } \\
\text { no. }\end{array}$ & $\begin{array}{c}\text { Time } \\
\text { (h) }\end{array}$ & $\begin{array}{c}\text { Peak area }(\mathbf{n}=3) \\
\text { Mean } \pm \text { SD }\end{array}$ & $\begin{array}{c}\text { \% } \\
\text { Degradation }\end{array}$ \\
\hline 1 & 0 & $2978072 \pm 11249.3$ & --- \\
2 & 2 & $2261113 \pm 10603.21$ & 24.02 \\
3 & 4 & $1892712 \pm 11079.36$ & 36.36 \\
\hline
\end{tabular}

TABLE 18: DEGRADANTS FORMED DURING OXIDATIVE DEGRADATION AT ROOM TEMPERATURE

\begin{tabular}{cccc}
\hline $\begin{array}{c}\text { S. } \\
\text { no. }\end{array}$ & Degradants & Retention time & $\begin{array}{c}\text { Peak area } \\
\text { Mean } \pm \text { SD }\end{array}$ \\
\hline 1 & $\mathrm{D}_{1}$ & 2.687 & $13974.33 \pm 73.6636$ \\
2 & $\mathrm{D}_{2}$ & 2.893 & $7010.02 \pm 38.9358$ \\
3 & $\mathrm{D}_{3}$ & 3.020 & $381943.7 \pm 1844.24$ \\
\hline
\end{tabular}

The drug showed highly liable to $\mathrm{H}_{2} \mathrm{O}_{2}$ at room temperature when compared to acid and alkali hydrolysis. It decomposed to the extent of $24.02 \%$ degradation in $0.3 \% \mathrm{H}_{2} \mathrm{O}_{2}$ in $2 \mathrm{~h}$. The degradation increased to $36.36 \%$ in $4 \mathrm{~h}$.

\section{Thermal Stress Study:}

TABLE 19: THERMAL DEGRADATION OF CAPECITABINE SOLUTION AT NMT $60^{\circ} \mathrm{C}$

\begin{tabular}{cccc}
\hline $\begin{array}{c}\text { S. } \\
\text { no. }\end{array}$ & $\begin{array}{c}\text { Time } \\
(\mathbf{h})\end{array}$ & $\begin{array}{c}\text { Peak area(n=3) } \\
\text { Mean } \pm \text { SD }\end{array}$ & $\begin{array}{c}\text { \% } \\
\text { Degradation }\end{array}$ \\
\hline 1 & 0 & 2042493 & -- \\
& & \pm 11276.63 & \\
2 & 2 & 1538681 & 24.60 \\
& & \pm 11409.74 & \\
3 & 4 & 1067370 & 42.41 \\
& & \pm 11507.09 & \\
\hline
\end{tabular}


TABLE 20: DEGRADANTS FORMED DURING THERMAL DEGRADATION OF SOLUTION AT NMT $60^{\circ} \mathrm{C}$

\begin{tabular}{cccc}
\hline $\begin{array}{c}\text { S. } \\
\text { no. }\end{array}$ & Degradants & Retention time & $\begin{array}{c}\text { Peak area }(\mathbf{n}=\mathbf{3}) \\
\text { Mean } \pm \text { SD }\end{array}$ \\
\hline 1 & $\mathrm{D}_{1}$ & 3.187 & $19029.02 \pm 73.2598$ \\
2 & $\mathrm{D}_{2}$ & 4.400 & $11989.67 \pm 21.7332$ \\
3 & $\mathrm{D}_{3}$ & 6.047 & $11936.04 \pm 74.0810$ \\
4 & $\mathrm{D}_{4}$ & 10.873 & $6227.33 \pm 70.0380$ \\
\hline
\end{tabular}

Discussion: The drug in solution form highly liable to thermal at temperature NMT $60{ }^{\circ} \mathrm{C}$ when compared to acid, alkali hydrolysis, and $\mathrm{H}_{2} \mathrm{O}_{2}$. The solution decomposed to the extent of $24.60 \%$ degradation in thermal in $2 \mathrm{~h}$. The degradation increased to $42.41 \%$ in $4 \mathrm{~h}$.

\section{Photodegradation:}

TABLE 21: PHOTODEGRADATION OF CAPECITABINE SOLUTION

\begin{tabular}{cccc}
\hline $\begin{array}{c}\text { S. } \\
\text { no. }\end{array}$ & $\begin{array}{c}\text { Time } \\
(\mathbf{h r})\end{array}$ & $\begin{array}{c}\text { Peak area }(\mathbf{n}=3) \\
\text { Mean } \pm \text { SD }\end{array}$ & $\begin{array}{c}\% \\
\text { Degradation }\end{array}$ \\
\hline 1 & 0 & $8403780 \pm 9701.546$ & --- \\
2 & 2 & $6025092 \pm 26410.42$ & 28.10 \\
3 & 4 & $3566527 \pm 36488.95$ & 57.24 \\
\hline
\end{tabular}

TABLE 22: DEGRADANTS FORMED DURING PHOTO DEGRADATION OF CAPECITABINE SOLUTION

\begin{tabular}{cccc}
\hline $\begin{array}{c}\text { S. } \\
\text { no. }\end{array}$ & Degradants & Retention time & $\begin{array}{c}\text { Peak area }(\mathbf{n}=\mathbf{3}) \\
\text { Mean } \pm \text { SD }\end{array}$ \\
\hline 1 & $\mathrm{D}_{1}$ & 4.367 & $3431.66 \pm 30.9892$ \\
2 & $\mathrm{D}_{2}$ & 4.820 & $2085.33 \pm 29.14332$ \\
3 & $\mathrm{D}_{3}$ & 6.060 & $1046.00 \pm 12.00$ \\
\hline
\end{tabular}

The drug showed higher liability to photodegradation at room temperature. It decomposed to the extent of $28.10 \%$ degradation in $2 \mathrm{~h}$. The degradation increased to $57.24 \%$ in $4 \mathrm{~h}$.

SUMMARY: In the present study, the API's namely capecitabine (anticancer) the essential therapeutic agent in the treatment of cancer.
Among the analytical techniques available in estimation and quantification HPLC method is an emerging technique reliable in vast areas of research that includes the other to undertake method development and validation as per ICH guidelines for the same.

In present work, forced degradation HPLC method has been developed for the estimation of capecitabine in marketed tablet formulation. Forced degradation The HPLC method was developed with the mobile phase system of $\mathrm{MeOH}: \mathrm{H}_{2} \mathrm{O}$ in the ratio of 60:40 v/v pH adjusted to 3 with orthophosphoric acid. The flow rate of $1 \mathrm{ml} / \mathrm{min}$ was used on a $\mathrm{C}_{18}$ column $(250 \times 4.6 \mathrm{~mm}, 5 \mu \mathrm{m}$ particle size). The retention time of capecitabine was observed at $6.97 \mathrm{~min}$ Table 23-24.

\begin{tabular}{|c|c|c|c|}
\hline \multicolumn{2}{|c|}{ Parameter } & $\begin{array}{c}\text { For } \\
\text { Capecitabine }\end{array}$ & Acceptance \\
\hline \multicolumn{2}{|c|}{ Retention time } & 7.927 & --- \\
\hline $\begin{array}{l}\text { LOD } \\
(\mu \mathrm{g} / \mathrm{ml})\end{array}$ & $\begin{array}{l}\text { Visualization } \\
\text { method }\end{array}$ & $1.477 \mu / \mathrm{ml}$ & ---- \\
\hline $\begin{array}{c}\text { LOQ } \\
(\mu \mathrm{g} / \mathrm{ml})\end{array}$ & $\begin{array}{c}\text { Visualization } \\
\text { method }\end{array}$ & $4.470 \mu / \mathrm{ml}$ & ---- \\
\hline Linearity & $(\mu \mathrm{g} / \mathrm{ml})$ & 4-40 & $\mathrm{R}^{2}=0.9991$ \\
\hline Accuracy & $20 \mathrm{mcg} / \mathrm{ml}$ & $101.61 \%$ & $98-102 \%$ \\
\hline Precision & Inter-day & $0.62 \%$ & \\
\hline (\%RSD) & Intra-day & $0.82 \%$ & $<2 \%$ \\
\hline Assay & $20 \mu \mathrm{g} / \mathrm{ml}$ & $101.43 \%$ & ---- \\
\hline Robustness & $0.8 \mathrm{ml}$ & 10.32 & Robust \\
\hline Flow rate & $1.2 \mathrm{ml}$ & 6.85 & \\
\hline Robustness & $58: 42$ & 9.16 & Robust \\
\hline $\begin{array}{l}\text { Mobile } \\
\text { phase }\end{array}$ & $62: 38$ & 7.21 & \\
\hline Robustness & $237 \mathrm{~nm}$ & 7.96 & Robust \\
\hline wavelength & $241 \mathrm{~nm}$ & 7.96 & \\
\hline System & Theoretical & 6814 & $>2000$ \\
\hline Suitability & plates & 0.54 & $<2 \%$ \\
\hline & $\%$ RSD & 1.19 & $0.9-1.2$ \\
\hline & Asymmetry & & \\
\hline
\end{tabular}

TABLE 24: SUMMARY OF FORCED DEGRADATION STUDIES REPORT

\begin{tabular}{ccccc}
\hline S. no. & Condition & Exposure & Result & No. of degradants found \\
\hline 1 & Acidic degradation & $0.1 \mathrm{~N} \mathrm{HCl}$ at room temperature & Degraded & 4 \\
2 & Alkali degradation & $0.1 \mathrm{~N} \mathrm{NaOH}$ at room temperature & Degraded & 3 \\
3 & Oxidative degradation & $0.3 \% \mathrm{H}_{2} \mathrm{O}_{2}$ at room temperature & Degraded & 3 \\
4 & Thermal degradation & Drug solution at NMT $60{ }^{\circ} \mathrm{C}$ & Degraded & 4 \\
5 & Photodegradation & Drug solution & Degraded & 3 \\
\hline
\end{tabular}

The developed and validated stability indication HPLC method is found be linear, accurate, precise, specific, and robust. Hence the method can be used routinely for estimation of capecitabine in formulations.

CONCLUSION: The present work was aimed at developing new validated RP-HPLC method for selected API and application to stability-indicating assay. The work was aimed comparatively to the earlier literature report in connection to the priority of the present investigation with respect to the $\mathrm{ICH}$ guideline parameters. In the present study, the API's namely capecitabine (anticancer) an essential therapeutic agent in the treatment of cancers. 
Among the analytical techniques available in estimation and quantification HPLC method is an emerging technique reliable in vast areas of research that indicated the author to undertake method development and validation as per $\mathrm{ICH}$ guidelines for the same.

The present work developed the RP-HPLC method for capecitabine by standard external method using MeOH: $\mathrm{H}_{2} \mathrm{O}$ ( $\mathrm{pH}$ was adjusted to 3 with orthophosphoric acid) (60:40 v/v) as mobile phase and detection was performed at $239 \mathrm{~nm}$ with a retention time of 7.927 min and peak asymmetry of 1.04.

The method was validated for all validation parameters as per ICH guidelines. The linearity range for capecitabine was $4-50 \mu \mathrm{g} / \mathrm{ml}$, with $\mathrm{r}^{2}$ value of 0.9991. The \% RSD for intra and interday precision was $<2 \%$. The method has been validated in the assay of tablet dosage forms. The accuracy of the method was validated by recovery studies and was found to significantly and under specification limits, with \% recovery 99-101.5 (within the acceptable range 98-102\%). The method also passed the specifications for robustness parameters.

A stability study on capecitabine was carried out, and an efficient HPLC method for quantification of capecitabine and identification of its degradation products in the bulk drug was developed and validated. The results of stress testing of the bulk drug, undertaken according to $\mathrm{ICH}$ guidelines, revealed that degradation products were formed under acidic, alkaline, thermal, oxidizing, and photolytic conditions.

ACKNOWLEDGEMENT: The writers are grateful to Dr. Y. Padmanabha Reddy, Principal, Dr. J. Ravindra Reddy, Vice-Principal and members of the Division of Pharmaceutical Analysis and Quality Assurance, Raghavendra Institute of Pharmaceutical Education and Research (RIPER), Anantapur for offering the required equipment, support and guidance during the thesis.
CONFLICTS OF INTEREST: Authors express no conflict of interest

\section{REFERENCES:}

1. Ramalakshmi S, Kavimani S, Srineevas S, Vetriselvi V and Bhaskar LVKS: Molecular Markers for Capecitabine Therapy: A Review. Int J Pharm Sci Res 2016; 7(11): 4315-26.

2. Anupama B, Jagathi V and Sai PP: Simultaneous estimation of gencitabine hydrochloride and capecitabine hydrochloride in combined tablet dosage form by RPHPLC Method. E-Journal of Chemistry 2011; 8(3): 121217.

3. Sreevatsav ASK and Harishbabu AK: RP-HPLC method development and validation of Capecitabine Extended Release Tablet dosage form. Int J Pharm Sci Res 2013; 4(11): 4477-87.

4. Jayaseelan S, Bajivali SK, Ramesh U, Sekar V and Perumal P: Bioanalytical method Development and validation of Capecitabine by RP-HPLC method. International Journal of Chem Tech Research 2010; 2: 2086-90.

5. Hoff PM, Ansari R, Batist G, Cox J, Kocha W, Kuperminc M, Maroun J, Walde D, Weaver C, Harrison E and Burger HO: Comparison of oral capecitabine versus intravenous fluorouracil plus leucovorin as first-line treatment in 605 patients with metastatic colorectal cancer: results of a randomized phase III study. J Clin Oncol 2001; 19(8): 2282-92.

6. Narendra D, Saikishore Y, Pushpalatha P, Mamatha N and Venkatesh P: Development and validation of new RP HPLC method for analysis of Capecitabine in pharmaceutial dosage form. IJSIT 2013; 2(1): 21-30.

7. Rajitha $\mathrm{K}$ and Nagavalli D: Validated estimation of Capecitabine by UV-Spectroscopic, RP- HPLC and HPTLC method. IRJP 2012: 3(11): 163-66.

8. Panikumar AD, Raju YV, Sunitha G, Ramakrishna K, Ceema $M$ and Venkateshwara RA: Development of validated stability indicating RP-HPLC method for the estimation of Capecitabine in pure and pharmaceutical formulations. International Journal of Research in Pharmaceutical and Biomedical Sciences 2011; 2(1): 17581 .

9. https://www.drugbank.ca/drugs/DB01101

10. Carr GP and Wahlich JC: A practical approach to method validation in pharmaceutical analysis. J. Pharm. Biomed. Anal 1990; 86: 613-18.

11. International Conference on Harmonization (ICH) Q2B. Validation of Analytical Procedures: Methodology; November 1996. Published in the Federal Register 1997; 62(96): 27463-67.

12. Monika B and Saranjit S: Development of validated stability-indicating assay methods-Critical review. Journal of Pharmaceutical and Biomedical Analysis 2002; 28: $1011-40$

How to cite this article:

Lalitha KV, Reddy JR and Devanna N: Validated stability indicating HPLC method for estimation of capecitabine. Int J Pharm Sci \& Res 2020; 11(11): 5651-58. doi: 10.13040/IJPSR.0975-8232.11(11).5651-58.

All $\odot 2013$ are reserved by the International Journal of Pharmaceutical Sciences and Research. This Journal licensed under a Creative Commons Attribution-NonCommercial-ShareAlike 3.0 Unported License.

This article can be downloaded to Android OS based mobile. Scan QR Code using Code/Bar Scanner from your mobile. (Scanners are available on Google Playstore) 